\title{
POTENTIALS FOR SUSTAINABLE USAGE OF KARST AQUIFERS IN SERBIA
}

\author{
Vesna Ristić Vakanjac ${ }^{1 *}$, \\ Maja Vujčić Trkulja², \\ Marina Čokorilo llić
}

${ }^{1}$ University of Belgrade, Faculty of Mining and Geology, Belgrade, Serbia

${ }^{2}$ Singidunum University, Belgrade, Serbia

\begin{abstract}
:
A rapid increase in population along with climate change has a major impact on the environment, access to food and water, human health, human migration, the economy of countries, politics. Due to the expected lack of water it is necessary to invest in exploring potential water resources that could mitigate the expected negative impact of climate change on water resources. The karstic spring waters represent the waters of an exquisite quality and as such can almost without treatment be used even for water supply. The regulation of these waters can greatly mitigate the water shortage due to long-term drought or mitigate the flood wave during the period of intense precipitation. On the other hand, their multiphase / stage economic valorization with an environmental approach can be of great importance to the environment and its sustainable development.
\end{abstract}

Keywords:

karst aquifer, regulation, climate change, economic valorization, and sustainable development

\section{INTRODUCTION}

The significance of groundwater is indicated by the fact that over than $70 \%$ of the population of Serbia is supplied by ground waters. The same situation is in Europe as well. A survey conducted for the purposes of the KINDRA project showed that in most parts of Europe, water is supplied from groundwater aquifers (European Commission, 2018). Here we are excluding Spain, Ireland and Ukraine, where groundwater is using in less than 30\% for water supplying (Ristić Vakanjac and Stevanović, 2016). Also, it should be noted that within the groundwater, karst aquifer waters stand out for their quality. On account of karst aquifer waters, water supplying is provided in some of the main cities in Europe, such as Vienna. Before the 18th century, the inhabitants of this city were supplied with water from the Danube alluvium. With the increase in population, there was pollution of the existing aquifer resulting in an increasing problem of groundwater quality in the Danube alluvium. A good example is when the problem of groundwater quality in the Danube alluvium becomes acute due to the increase of the population in Vienna. As a fact of this, during the 17th, 18th and even 19th centuries, cholera and typhoid outbreaks have been extremely dominant. For this reason, for the needs of the emperor palace at that time the water was brought in barrels with the help of horses and donkeys from distant karst springs (figure 1). Also, waterman and water-women sold some amount of this water to the population of Vienna.

Due to present situations, immediately after his arrival on the throne, Franz Joseph started with solving water supply issue, in aim to stop current epidemics. The idea was to bring this water to every user in Vienna without waterman and waterwoman service. The construction of this waterworks began in 1869 and ended in 1873.
Correspondence:

Vesna Ristić Vakanjac

e-mail:

vesna.ristic@rgf.bg.ac.rs 
The water supply system that tapped water of the karst spring Kaiserbrunn (translated as "the emperor spring") opened by Franc Joseph personally (figure 2). The length of the pipeline from the tapped spring to Vienna is about $120 \mathrm{~km}$. In this way, problematic outbreaks have been permanently eliminated. During the 20th century, water from several other springs along the pipeline route and in the vicinity of Kaiserbrunn was connected to the first water supply system.

Figure 1: The transfer of quality drinking water from distant karst springs (photo B. Vakanjac)

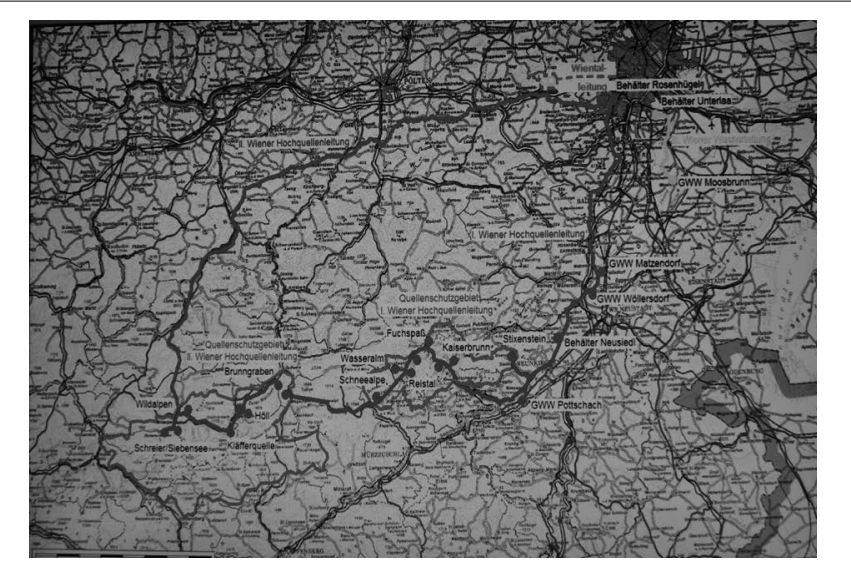

Figure 2: Kaiserbrunn - first tapped karst spring for Vienna water supply (photo B. Vakanjac)

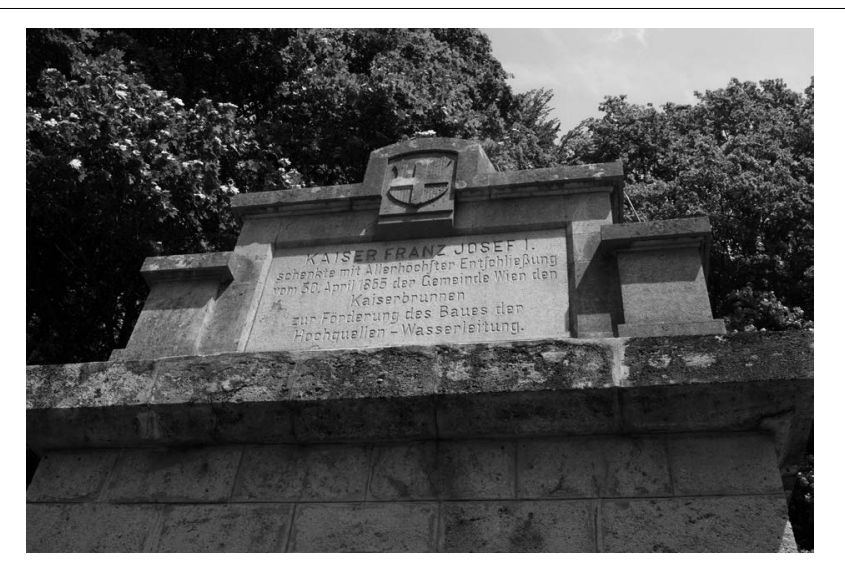

\section{METHODOLOGY}

Karst water regime

To comprehend karst aquifer water through the circular economy, first of all something needs to be said about the regime of quantitative and qualitative parameters of that groundwater. Generally speaking, we distinguish springs which having gravity type of discharge (descending) and springs that have ascending type of discharge (under pressure) (Bonacci, 1987; Bonacci, 1993; Kresic \& Bonacci, 2010; Kovács, Perrochet, Király \& Jeannin, 2005).

The regime of gravity type karst springs depends mainly on the precipitation regime (melting snow cover and heavy intensity precipitation). Some of the most wellknown springs of this kind in Serbia are the Veliko and Malo spring (southern Beljanica), then the Sjenica spring, the spring Banja (Petnica spring) and the Perućac spring. Their main characteristic involves a steep increasing (rising limb) and steep decreasing discharge hydrograph - recession limb (figure 3). During the periods of high flow regime, in most cases appears turbidity and high number of total bacteria (figure 4). If such springs are tapped for water supply, water is not useful for consuming and that water source have to be disconnected from the central water supply system until turbidity drops below the allowable value. In addition to turbidity and increased number of bacteria that are present during the high flow regime, there is also a problem during dry periods. Some karst springs during the dry period are completely dry. For other springs that have discharging during the whole year, during dry periods the flow drops below the biological minimum, so these quantities cannot be used for any purpose (Stevanović, 2015).

Figure 3. Comparison of daily precipitation totals and discharge hydrograph (July, 1997), (Ristić Vakanjac, et al., 2015)

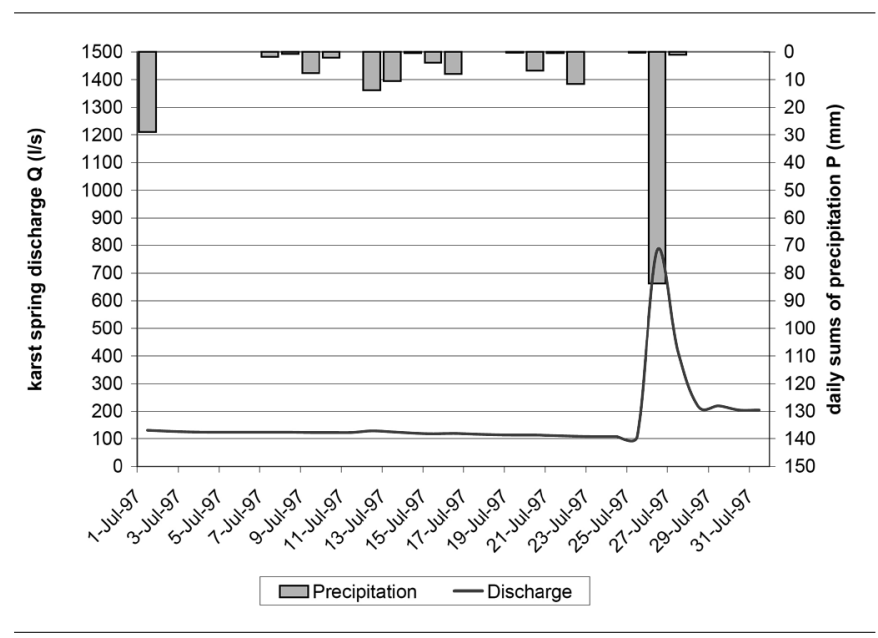

Figure 4. Parallel representation of discharge, total bacteria at Banja karst spring and precipitation recorded in the catchment in 1991. (Ristic Vakanjac, 2017)

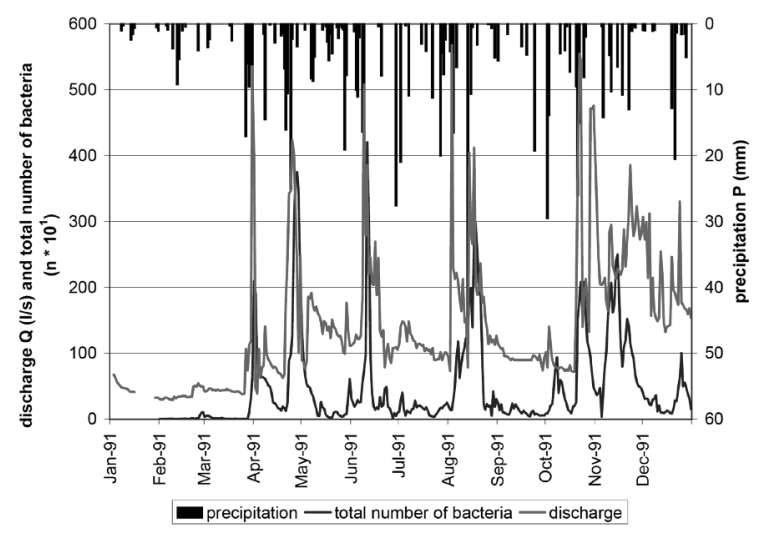


A regime of ascending type of karst springs also depends on the regime of precipitation and snowmelt dissolution, although its impact, i.e. the increasing discharge hydrograph, occurs after some period of delay. The decreasing part has a much milder slope (example of karst spring Vapa - figure 5). The recession period has a long duration and the dynamic reserves are generally more significant relative to the dynamic reserves of gravity springs (figure 5). Also, the regime of quantitative parameters (bacteriology and turbidity) is much more stable. Some springs have never had a problem with turbidity increasing - for example, the Kavak spring which is using for Pirot water supply (figure 6).

Figure 5. Typical hydrograph of the Vapa Spring (Ristić Vaknjac etal., 2016)

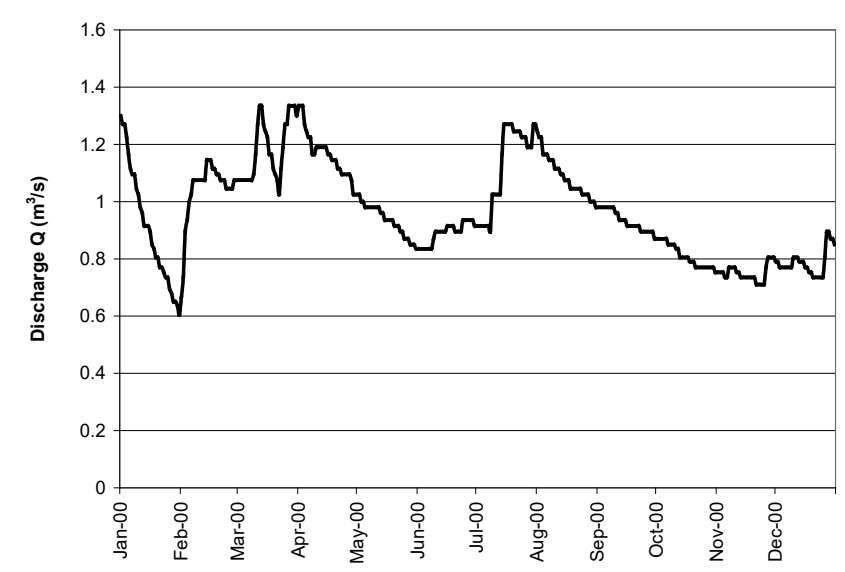

Figure 6. Discharge of the karst spring Kavak (Ristić Vakanjac et al., 2012)

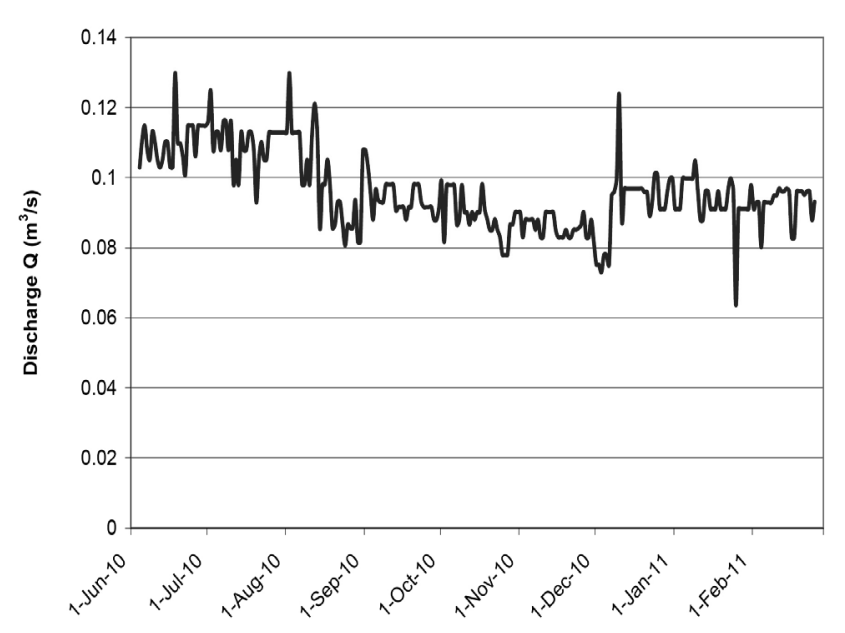

\section{Potential of karst aquifer waters}

In general, karst areas in many countries are under some kind of protection. Ground water from karst terrains can be used in the following ways: water supply, irrigation, fish farming, hydropower, tourism and fishing.

Water supply: As stated, karst aquifer waters are mainly used for water supply. The quality of groundwater is such that can be used in their natural state. Due to the aforementioned problem of the appearance of turbidity, if the karst spring is tapped, during the periods of turbidity greater than 1 NTU (Nephelometric Turbidity Units) comes to short-term exclusions of these waters from the central water supply system. Another solution is mixing these waters with low turbidity waters in order to reduce turbidity value below 1 NTU.

Irrigation: Within the karst terrains often aquifer levels are at great depths. To get to this quality water it's necessary to perform deep drilling that requires large investments. Also, karst massifs are mostly sparsely populated, so there are no needs for significant amounts of water. These residents mostly use rainwater, which is kept in the cisterns (term "čatrnje") for the purposes of water supply and irrigation. Usually within the doline forms, a layers of terra rossa is formed, within is being done certain, smaller agricultural production (Cernatič-Gregorič \& Zega, 2010). Larger settlements are around the perimeter of karst massifs where mostly dominant are the intergranular aquifers which are also recharged from karst aquifers. Also, karst springs are present in these areas. Here, agricultural production is more significant, so they are needed more significantly quantities of water for irrigation purposes. In these parts irrigation is being done mainly from shallow dug or drilled wells where groundwater levels are at shallow depths, or they can use water of karst springs.

Fish farming: As these waters are of high quality, cold and oxygen rich, most often downstream from the point of discharging karst spring, fish ponds were built where it is farming trout, salmon trout, California trout, etc.

Hydropower: We live in a time when everyday life is unthinkable without electricity. There is an idea as well as cadastre of potential position for SHPP (Small Hydroelectric Power Plant). Some of these potential positions are within karst terrains, more precisely along the perimeter of karst massifs. On the one hand, electricity produced in this way does not belong into the category of environmental pollutants. But on the other hand, these areas are mostly protected areas due to biocoenosis, which resides here as well as geological and hydrological objects that are under some form of protection. In such cases, placing these high quality waters in the pipes for energy production can permanently impair biocoenosis, which may only, exists in that kind of area. 
Tourism and fishing: Here we can mention ecotourism, geo-tourism and rural tourism (Handoko, 2019). Ecotourism as a special branch of tourism usually takes place within ecologically safe environments that are mostly known as protected areas. Geo-tourism as a branch of tourism gives tourists the opportunity to visit attractive geological, geomorphological, hydrological and hydrogeological objects that are abundant within the karst terrain (geodiversity sites). This kind of activity could be organized with establishing walking and hiking trails. . These grounds are mostly uninhabited, i.e. there are smaller settlements like villages; so as part of their ecosystem services, rural tourism can be developed. Also, karst springs form fast streams and rivers rich in mountain fish, so sports activity such as eco-fishing could find its place here.

\section{CIRCULAR ECONOMIES AND KARST AQUIFER WATER}

High quality of karst water can be used without disturbing the natural ambience of a protected area; also, that water can be used in a way of circular economics without compromising their quality and environmental disturbances.

At the first place, it is necessary to provide certain quantities of water for the purposes of water supply. It was mentioned that these terrains are not heavily populated, so that no larger or more significant quantities of waters are needed for these purposes. For water supply, the average is around $180 \mathrm{l} / \mathrm{day} /$ resident. For a settlement of 10.000 inhabitants (Bela Palanka municipality has 8143 inhabitants according to the 2011 census) it is necessary to have around $1800 \mathrm{~m} 3 /$ day for settlement water supply, i.e. it is necessary to provide $21 \mathrm{l} / \mathrm{s}$ for the whole settlement. Due to the unevenness of day and night consumption, we can say, for safety, that it is necessary for such a small town, only for water supplies it has to be provided about $30 \mathrm{l} / \mathrm{s}$. So part of these quality waters in an appropriate amount goes to the water supply. The rest of karst water from karst springs forms stream. One of the potentials of karst water lays in forming a small lake, which could represent a natural pond. In the area where the natural dam was installed, grids and netting would be established for the purpose to control passage of trout. Below the dam a water mill could be built which would in the natural way use the power of water for grinding organic grains. Also, within the water mill the wheel could be connected with power generation system, which could supply the water mill and surrounding houses with electricity. And finally downstream from the water mill, the water that is still, by its quality unchanged, could also be partly used for agricultural irrigation. Only a lake that would be stocked can be used for sport fishing while the natural undisturbed environment could attract tourists of different interests.
The potential of karst aquifer water reflects in the development of its infrastructure that can serve multiple functions: offering green space, delivering clean water, providing energy and transportation options and generating new economic evolvent (Georgia Tech Civil and Environmental Engineering Department, 2017).

\section{CONCLUSION}

Karst aquifer waters represent high quality waters. In some cases, the quality of these waters is such, that they can be used for water supply during the whole year in its natural state. Occasional turbidity of karst aquifer can be overcome by tapping static reserves of karst waters. Also, the mentioned problem that appears during the dry periods (lack of water) could be resolved by regulating the karst aquifer. An overview of the circular economy concept and design processes for a regenerative economy can shelter karst aquifer waters as a sustainable water supply that rests on nature-based principles, keeping products and materials in use, and regenerating natural systems. In this way it is possible to live in symbiosis with nature without disturbing the original ambience.

\section{REFERENCES:}

1. Bonacci, O., 1987. Karst Hydrology; Springer: Herdelberg, Germany.

2. Bonacci, O., 1993. Karst springs hydrographs as indicators of karst aquifers. Hydrol. Sci. J. 1993, 38, 51-62.

3. Cernatič-Gregorič, A., Zega, M., 2010. The Impact of Hu-man Activities on Dolines (Sinkholes) - Typical Geomor-phologic Features on Karst (Slovenia) and Possibilities of their Preservation, Geographica Pannonica. Volume 14, Issue 4, 109-117

4. European Commission, 2018. Digital Single Market for Water Services Action Plan Luxembourg, Publications Office of the European Union. ISBN 978-92-79-79351-6

5. Georgia Tech Civil and Environmental Engineering department, 2017. Fairmount Park, Philadelphia, PA. (CPA_Park-Cases-FINAL-red.pdf)

6. Handoko, V. S., 2019. Domination among tour operators in Karst conservation area of Goa Pindul, Indonesia, International Journal of Economic Policy in Emerging Economies, 2019 Vol.12 No.2, pp.175 - 181

7. Kresić, N.; Bonacci, O., 2010. Spring Discharge Hydrograph. In Groundwater Hydrology of Springs;

8. Kresic, N., Stevanovic, Z., Eds.; Butterworth-Heinemann: Oxford, UK

9. Kovács, A., Perrochet, P., Király, L., Jeannin, P., 2005. A quntitative method for characterization of karst aquifers based on the spring hydrograph analysis. J. Hydrol. 303, 152-164. 
10. Ristić Vakanjac, V., Golubović, R., Polomčić, D., Čokorilo Ilić, M., Štrbački, J., Bajić, D., Ratković, J., 2017. Autocorrelation and cross-correlation analyses of total bacteria: Case study of Banja karst spring in Valjevo, Serbia, Proceedings of the national conference with international participation „Geosciences 2017“ , pp.145-146. Bulgarian Geological Society Sofia

11. Ristić Vakanjac, V., Čokorilo Ilić, M., Milanović, M., Jovanov, K., Vasić, Lj., 2016. Autocorrelation analyses of karst spring discharges regimes, III Congres of geologist of Republic Macedonia with international participiant, (ed. Lepitkova S. and Boev, B.), Macedonia, Struga, pp. 85-92.

12. Ristić Vakanjac, V., Stevanović, Z., 2016. Projekat KINDRA - Inventar podataka o hidrogeološkim istraživanjima, $X V$ Srpski simpozijum o hidrogeologiji sa međunarodnim učešćem, Rudarsko-geološki fakultet, Univerzitet u Beogradu, pp. 529-532, Kopaonik, Srbija

13. Ristić Vakanjac, V., Papić, P., Golubović, R., Vakanjac, B., Čokorilo Ilić, M., Jokić, M., 2015. Karst gorundwater budget and discharge regime of Banja Spring near Petnica, Journal of Geographical Institute "Jovan Cvijic", SANU, Vol. 65/1, pp 19-32, ISSN 0350-7599

14. Ristić Vakanjac, V., Stevanović, Z., Milanović, S., 2012. WP4-Availability of Water Resources, Monography: Climate Changes and Impacts on Water Supply (Editors: Stevanović Z., Ristić Vakanjac V., Milanović S.), Univerzitet u Beogradu, Rudarsko-geološki fakultet, Beograd, pp 133-176. ISBN 978-86-7352-263-0

15. Stevanović, Z., (2015). Karst Aquifers - Characterization and Engineering. Prof. Pract. Earth Sci. 